\title{
THE FORMATION OF NOBLE MORALS IN MADRASAH ALIYAH NEGERI (MAN) IN WEST JAVA
}

\author{
Novi Rizal Umam \\ Madrasah Tsanawiyah Muhammadiyah Rancaekek \\ Email: novi.rizal.umam@gmail.com \\ Sutaryat Trimansyah \\ Universitas Islam Nusantara \\ Email: yatsutaryat@ymail.com \\ Ikka Kartika \\ Universitas Islam Nusantara \\ Email: ikkakartika@hotmail.com \\ Yosal Iriantara \\ Universitas Islam Nusantara \\ Email: yosaliriantara@uninus.ac.id
}

Office: jalan KH. A. Syad]li no 57 rt 02/21 desa jelrgong kec rancaekek kab bandung

\begin{abstract}
This study focuses on the issue of the formation of noble morals in MAN 2 Bandung City and MAN 2 Bandung Regency. This research uses a qualitative approach with a qualitative descriptive method. In this study, it discusses how the management system for the formation of noble morals in educational units, especially in MAN 2 Bandung City and MAN 2 Bandung Regency responds to new challenges in this era of globalization which have resulted in many decreases in the quality of human resources, especially related to embedded moral decadence. in students. Besides, it discusses various environmental influences that affect the implementation of the noble character formation program and various problems that arise from the noble character formation program along with the solutions to its solutions. This research shows that the managerial system for the formation of noble morals in the education unit has implemented management principles through the stages of planning, implementing, monitoring, and evaluating every noble character formation program with various advantages and limited resources. This stage is an effort to reduce the increasing level of moral decadence. The many influences and problems that arise are taken into consideration in formulating various strategies as solutions to these problems.
\end{abstract}

Keywords: Management, Moral Noble, MAN 2 Bandung

\section{A. INTRODUCTION}

Globalization, modernization, and the development of science and technology have brought society to a new, more open order. The era of globalization has given rise to an increase in the global activity which is marked by the tendency of the loss of geographic boundaries and the very rapid exchange of information in aspects of people's lives. This trend can certainly affect the lives of people in certain areas of the world.

Indonesia is a country that cannot be separated from the current globalization. This can be a challenge to aspects and aspects of community life, including those related to cultural and religious issues which have been a set of social institutions that regulate human activities and actions. If the locality elements that are owned by the community are in direct contact with global elements, then this could be possible for the emergence of a serious threat to the existence and stability of culture and religion that has been 
adhered to. In the end, the logical consequence faced by the Indonesian people is the potential for a decline in the quality of human resources in the future.

Currently, Indonesia is feeling signs of a decline in the quality of its human resources. This is indicated by the problem of moral decadence in several regions in Indonesia. Information from the Ministry of Health of the Republic of Indonesia obtained data that in 2016 the prevalence rate of drug abuse in general in Indonesia reached $2.21 \%$ or equivalent to $4,173,633$ people (Kementerian Kesehatan RI, 2017. p. 4). The National Narcotics Agency in its release published by Republika.co.id on October 30 , 2017 stated that in 2016, student and student drug users reached $21.27 \%$. Promiscuity among adolescents also has a significant contribution to the moral decadence that occurs. Data from the Central $\mathrm{PKBI}$, also states that the Annisa Foundation's research in 2006 involving junior high and high school students in Cianjur (JABAR) revealed that $42.3 \%$ of students had had sex for the first time in school (BKKBN, 2016). According to Fitri there are several variables related to student sexual acts, including: exposure to mass media, the role of parents, the role of peers and the role of educators (Fitri, 2017. p.70).

Moral decadence is one of the negative impacts that arise and must be faced by the Indonesian people. This condition is inseparable from the flow of information that runs very fast and is difficult to contain. Therefore, the right strategy in responding to these conditions is the role of education. Education plays a very important role in developing and preparing human resources who are not only superior scientifically but also in terms of morals so that the younger generation is expected to be independent and wise in filtering information for themselves. So that inclusive moral education is needed in the school curriculum (Njoku, 2016. p. 191).

Moral development is one of the non-negotiable orientations of Islamic education. Of course, reforms must be carried out thoroughly and touch various aspects to respond to global challenges and prepare for the competition and opportunities of the global era with the accompanying consequences (Tantowi, 2008. p.99). The efforts of the State of the Republic of Indonesia to develop Human Resources (HR) through education are intended so that Indonesian human resources have expertise and competitiveness and have noble morals. This is under the mandate of Law No. 20 of 2003 concerning the National Education System (UU SISDIKNAS), chapter I article 1 which states that:

Education is a conscious and planned effort to create an atmosphere of learning and the learning process so that students actively develop their potential to have religious-spiritual strength, self-control, personality, intelligence, noble character, and skills needed by themselves, the people of the nation, and the State (Depdiknas, 2003).

Based on the SISDIKNAS Law above, it shows that education in Indonesia is directed at the formation of human resources who have religious-spiritual strength, self-control, personality, intelligence, noble morals and skills needed by themselves, the people of the nation, and the State so that Indonesian human resources are competitive with those of the State. other. Besides, what is stated in it, this is a sign that a continuous education process can give birth to students who have noble morals so that they can become part of the national character.

Character education is the creation of a school environment that helps students develop ethics, responsibility through models, and teaching good character through universal values (Berkowitz \& Bier, 2005, p.7). Sauri mentions character education as value education. According to him, value education is the soul or spirit in education. The value in question is a value that helps humans to live better together with other people in their world (learning to live together) towards perfection (Sauri \& Firmansyah, 2010. p.30). Character education can affect the noble morals of students if it is carried out integrally and simultaneously in the family, class, school environment, and society (Raharjo, 2010. p.237). 
The implementation of moral formation in the educational unit has been carried out, especially at the level of cognitive recognition, but the low level of program management has resulted in the formation of noble morals not being internalized into the daily lives of students. Maybe this is due to not running optimally the moral formation program for students. This condition is also influenced by variations and innovations in moral formation programs that are integrated with the curriculum. Besides, cooperation between the education unit and the parents of students is not well established, as a result, the formation and habituation of morals are only carried out at school but not at home.

Madrasah Aliyah (MA) is one of the levels of secondary education informal education in Indonesia, equivalent to Senior High School (SMA) or Vocational High School (SMK), which is managed by the Ministry of Religion. MA education is taken within 3 years with $30 \%$ of the curriculum being religious lessons. With a higher proportion of religious lessons compared to other educational units, Madrasah Aliyah can be able to hone and shape the noble morals of students. This system is expected to build the noble morals of students so that they can adapt themselves sustainably to their living environment but remain firm in principles (Sanusi, 2015. p.92).

Based on the above, it is necessary to carry out related research first, the managerial system of the education unit at the Madrasah Aliyah Negeri level in West Java which is oriented towards the process of shaping the morals of students. Second, various environmental influences that influence the implementation of the noble character formation program. Third, various problems arise from the noble character formation program along with the solutions to its solutions.

\section{B. METHOD}

The approach in this research is qualitative research with qualitative descriptive methods. Descriptive research is collecting data based on factors that support the object of research, then analyzing these factors to look for their roles (Arikunto, 2005. p.151). This method is used to obtain in-depth data, data that contains meaning. This method is expected to directly present the nature of the relationship between researchers and informants, research objects, and subjects.

The data source used is based on two data sources, namely primary data sources and secondary data sources. The primary data source or the first source in this study are the Head of Madrasah, Deputy Head of Curriculum, Deputy Head of Student Affairs, program coordinator/person in charge, BK teachers, students, parents of students. Meanwhile, secondary resources, namely data arranged in the form of documents that function as supporting and complementary data from the first source. The data were collected using interview techniques, observation, and documentary studies which were then analyzed by the process of data reduction, data presentation, and concluding. Meanwhile, the location of this research was carried out at MAN 2 Bandung, which is located at Jalan Cipadung no. 57 Cibiru District, Bandung City, and MAN 2 Bandung Regency which is located at Jalan Sastra No. 21 C, Solokan Jeruk District, Bandung Regency.

\section{RESULTS AND DISCISSION}

\section{Akhlak}

The word morality comes from an Indonesianized Arabic which is also interpreted by the term temperament or politeness. The word akhlak is the plural taksir of the word (Khuluku) which etymologically means character (al sajiyyat and al thab) manners, wisdom, religion (al din). According to moral experts, it is a state inherent in the human soul, from which deeds are born easily, without going through a process of thought (spontaneously), consideration, or research. Morals are usually referred to 
as human spirit encouragement in the form of good and bad deeds (Mujieb, 2009. p.38). The moral dimension does not only have a horizontal relationship dimension between fellow humans, but also has a vertical relationship dimension between humans as servants and Allah SWT as God.

\section{Definition of Education}

When viewed from an Islamic perspective, education is an anthropological phenomenon whose age is almost the same as human history itself, where Allah SWT created the first human, namely Prophet Adam AS. Niccolo Machiavelli in Koesoema understands that education is a framework for the continuous process of human self-improvement. This happens because by nature humans have shortcomings and incompleteness for him, human intervention through education can complement imperfections in human nature (Koesoema, 2010. p.52).

Meanwhile, the meaning of education in Law no. 20 of 2003, Chapter I article I, that education is a conscious and planned effort to create a learning atmosphere and learning process so that students actively develop their potential to have religious spiritual strength, self-control, personality, intelligence, noble character, and skills that are needed by himself, society, nation, and state (Depdiknas, 2003).

Both of these meanings that education has the same meaning, namely completing or developing human nature by developing potential for a better direction for himself and his environment, which is done deliberately and planned according to the goals of self-development to be achieved. Meanwhile, according to Alfred North Whitehead in Tafsir, in a narrow sense states that education is the development of skills using knowledge. Skills arise because they are based on knowledge. Therefore, education is seen as a preventive alternative because it is for the sake of building a dignified national generation. As a preventive alternative, education is expected to develop the quality of the nation's young generation in various aspects that can suppress the causes of the decline in cultural problems and national character. Based on the explanation above, it can be concluded that education is a conscious and planned effort to instill value in students to create competitive and noble human beings (Tafsir, 2005. p.26).

\section{Educational Functions and Objectives}

Concerning the functions and objectives of education, as stated in Law No. 20 of 2003 Article 1, it states that:

"National education has the function of developing capabilities and shaping dignified national character and civilization to educate the nation's life, aiming to develop the potential of students to become human beings who believe and fear God Almighty, noble, healthy, knowledgeable, competent, creative, independent, and become a democratic and responsible citizen" (Depdiknas, 2003).

In this Law, there are two functions of national education, namely the development of abilities and character. Every human being is inseparable from the environment and his life, the ability to become an asset for every human being to survive and socialize so that he becomes an independent human being, able to develop his life and fulfill his life with the abilities obtained from education. Likewise, moral character or character as a support for living side by side with other people in small and large communities so that moral persons are formed which are aimed at moral attitudes and actions, and this is the goal of education, namely to be a faithful and righteous human being. have a noble character, healthy, knowledgeable, capable, creative, independent, and become democratic and responsible citizens. Thus, that education is an effort to guide or guide someone so that abilities develop and moral behavior is formed so that a dignified society is formed, this is the purpose of education. 
According to Sanusi in Mulyasana, the function of education is that in addition to being directed towards transforming positive values, it is also developed as a tool to empower all potential students to grow in line with the demands of religious, social, economic, educational needs. politics, law, and others. To function education proportionally, improvements must be made at all strategic levels such as from policies, managers, and implementers of education (teachers) (Mulyasana, 2011. p.6).

Furthermore, Mulyasana, the objectives of national education in detail can be explained as follows (Mulyasana, 2011. p.7):

1) The development of the potential for faith and piety.

2) The formation of noble morals of students.

3) Forming healthy students.

4) Print knowledgeable students.

5) Print competent students.

6) Forming the independent soul of students.

\section{Moral Education}

Moral education is education regarding the basics of morals and the virtues of character, traits that must be owned and made into a habit by children from the time of analysis until they become a mukallaf, someone who is ready to navigate the oceans of life. He grows and develops based on the foundation of faith in Allah and is educated to always be strong, remembers to lean on, ask for help, and surrender to $\mathrm{Him}$, so he will have potential and an instinctive response in receiving every virtue and glory. Besides accustomed to doing noble morals (Rahardjo, 1999. p.63).

\section{Scope of Moral Education}

The scope of moral education is no different from the scope of Islamic teachings relating to the pattern of their relationship with God, fellow creatures, and the universe (Sholihin \& Anwar, 2005. p.31). Morals to Allah SWT are attitudes or actions that humans as creatures should do to God as Khaliq. Morals to Allah are worshiping Allah SWT, love for Him, love for Him, do not associate with Him. Give thanks only to Him and so on. Morals to fellow humans.

According to Hamzah Ya'cob, morals towards fellow humans are the attitudes or actions of one human being towards another. Morals towards fellow human beings include morals towards parents, morals towards siblings, morals for neighbors, morals for fellow Muslims, morals for the weak, including morals for others, namely morals for teachers who are instrumental in providing knowledge. So a student is obliged to respect and maintain the authority of the teacher, always be polite to him both in speech and behavior, pay attention to everything he teaches, obey what he is ordered to do, listen to and carry out all his advice, also not do things that are prohibited or prohibited disliked (Ya'cob, 1978. p.19). Morals to the environment are everything around humans, be it animals, plants, or inanimate objects (Nata, 2009. p.152).

\section{Planning for the Formation of Noble Morals in MAN 2 Bandung City and MAN 2 Bandung Regency}

To realize students who have noble morals, MAN 2 Bandung City and MAN 2 Bandung Regency have developed a strategy through a careful planning process. This planning is done as the first step in a working mechanism that is based on basic management principles. Referring to the theory of George R. Terry regarding the planning process, MAN 2 Bandung City and MAN 2 Bandung Regency to realize the formation of noble morals in students is carried out by referring to the vision, mission, and objectives of the madrasa. Of course, the executor of the noble character formation program must go through the steps 
and strategies for the preparation. Educators have an important role in this process. This is because they as planners and implementers of noble character formation programs who directly deal with students in the madrasa environment.

Formulation, drafting, and deciding are part of the planning process. The steps starting from the formulation to termination of this policy are determined and agreed upon with the madrasa community, which includes educators and education staff as well as parents.

Various supporting aspects that are an important part of the plan include human resources and facilities or facilities that will later become part of the program implementation. These human resources include educators and education personnel including committees and parents of students. Also, the supporting facilities consist of atirbut and equipment for intra and extra-curricular activities as well as a means of worship for school residents. In the planning process, the two madrasas make a decision based on consideration and rationality in choosing and determining the actions to be taken. This is by considering conditions at this time and the possibilities that will occur in the future.

The planning stages in MAN 2 Bandung City are led by the head of the madrasah by conducting a leadership meeting as the first step in planning. The implementation of this leadership meeting is generally held at the beginning of the school year. The planning discussion in this leadership meeting uses SWOT analysis. The results of the analysis will later become the basis for designing and formulating program planning including issues regarding the formation of noble morals.

This is different from the planning carried out in MAN 2 Bandung Regency. Implementation of a leadership meeting, first a transition meeting from the old leadership to the new madrasah leadership is held. This aims to avoid mistakes and misunderstandings in realizing any programs that have been established by the previous leadership, as well as to continue the implementation of old programs that are considered important, to improve the quality of students, especially in the quality of their morals.

The birth of a work program resulting from the formulation, compilation, and mutual agreement between madrasah citizens who have gone through a process of adjustment with supporting sources, will determine the implementation of the next program. So that the success of the noble morals formation program may be determined by how the madrasa residents can make the design carefully. This process is of particular concern to the two madrasas.

In general, the preparation of programs that are planned to be carried out at the beginning of the school year involving various parties. In it discusses how the previous challenges, obstacles, and successes have been achieved. Then, formulate a new plan that feels ripe, which will then go through a process of socialization to existing components in the madrasa environment, both to educators, education, committees, parents of students, and to students.

\section{Implementation of the Noble Moral Formation Program in MAN 2 Bandung City and MAN 2 Bandung Regency}

The implementation of the noble character formation program in MAN 2 Bandung City and MAN 2 Bandung Regency through an enrichment program integrated into five categories consisting of the formation of noble morals which is integrated into all subjects; habituation of worship practices; literacy activities; extracurricular activities, student organizations; and supporting facilities that facilitate the activities of educators and students. The implementation of the formation of noble morals requires synergy between stakeholders and program targets, namely students who are supported by various systems and infrastructure. 
The two madrasas have taken the same steps to bring about the birth of students with noble character. This step includes the process of socializing the parents/guardians of students. This stage is the initial stage to implement the noble morals formation program. For both madrasas, this stage is very important to do. This is done not only to carry out the task of educators but also to build trust in the community, so that stakeholders in the madrasa environment can collaborate and collaborate with the community to create students who have noble morals.

The second step was carried out by the two madrasas, namely the implementation of programs that had been planned and prepared in advance. This step is a concrete form of all madrasah efforts to realize shared expectations between stakeholders in the madrasah environment and the parents/guardians of students. Educators and education in the madrasa environment have an important role in shaping the morals of students.

The implementation of the noble character formation program is divided into five categories. In grouping the noble character formation program of students, it is generally integrated into the main activities of the school. However, in detail, each madrasah has different programs. Likewise, the implementation of a relatively different noble character formation program. The five main madrasah programs contain content and moral values, both explicitly and implicitly, becoming the main pillars and even the pillars of the madrasah. The five morality formation programs, namely:

\section{1) Establishment of Noble Morals in Subjects}

The formation of noble morals can be integrated into the curriculum (Mulyasa, 2014), (Nursanti, 2014), (Samanai et al., 2017). One of the contents contained in the curriculum is developed into subjects. The formation of noble morals into this learning subject can develop the potential of students not only cognitively, but also social and spiritual values which will be reflected in the behavior of students.

Lickona emphasizes the importance of three components of noble character or morals in students. First, moral knowings related to morawarenessess, knowing moral value perspective-taking, moral reasoning, decision making, and self-knowledge. Second, moral feeling related to conscience, self-esteem, empathy, loving the good, self-control, and humanity. Third, moral action consists of a combination of moral knowing and moral feeling which are manifested into competencies, desires, and habits. These moral values include components: awareness, understanding. The values of noble morals that are reflected in essence are explicitly or implicitly contained in the Content Standards and learning tools in each subject and department in the madrasah (Lickona, 2013).

Learning tools are one of the important instruments for their existence. The contents contained in it contain a concept that can encourage students to be able to instill these values into their personal life in society. Learning materials related to norms or values in each subject are developed and made explicit according to the context of everyday life (Samanai et al., 2017. p.111), (Mulyasa, 2014. p.8).

In its implementation, educators who teach subjects in MAN 2 Bandung City and MAN 2 Bandung Regency make a Learning Implementation Plan (RPP) which contains content and values of character building by referring to the 2013 curriculum which emphasizes social and spiritual aspects. The two madrasas compile this learning plan into subjects with a collaborative learning model after assessment and review.

In this case, the role of educators who teach subjects is very important. He compiles and implements learning plans in the learning process with students. This process does not escape the attention of 
educators in the environment of MAN 2 Bandung City and MAN 2 Bandung Regency. Each component in the madrasah environment prepares a lesson plan concerning the vision, mission, and objectives of the madrasah. Also, in the formulation process, educators coordinate, especially with the head and deputy head of the madrasah curriculum, directly.

\section{1) Habitual Practices of Worship}

In addition to the implementation of the formation of noble morals that are integrated into subjects, habituation of worship practices is one of the actions that can form noble morals in students. Various programs designed by the madrasah have become spaces for students to be able to apply themselves from what they get during class learning. Madrasahs introduce directly some obligatory worship practices and sunnah as well as categories of worship that are ritual and socially oriented worship. This space is the concentration of madrasas to be managed properly and optimally. The head of the madrasah, including all teaching educators, creates madrasah conditions that can encourage students to get used to good habits according to Islamic principles (Djailani, 2013).

To realize these ideals, as the first step students are directed to always carry out activities that have been programmed on an ongoing basis. Furthermore, educators conduct surveillance and monitoring of the course of the program. These activities are carried out continuously so that they become habituation. Habit can be defined as certain behaviors that are carried out automatically without a plan and done without thinking (Cinantya, 2019). Therefore, repeated good actions will become a good habit as well.

Some of the categories of worship defined by the two madrasas appear to differ in terms of their programs and implementation mechanisms. In MAN 2 Bandung, the practice of worship is a ritual, which includes obligatory prayers in the congregation to be carried out periodically from Monday to ThursdAlsotion, the Sunnah Duha prayer is held every Tuesday and Friday prayers.

Technically, the implementation of the practice of praying, both mandatory and sunnah, students havhasrole as objects as well as subjects in implementing the programs that have been made. Students are directed to be able to carry out the program as well as to be able to coordinawith te their friends to prepare themselves for the implementation of worship.

Meanwhile, MAN 2 Bandung Regency, carries the concept of implementing the practice of worship by making instruments, namely making guidebooks intended for students. Through the guidebook, program implementation is more organized and orderly and can monitor the involvement of students as a whole.

In addition to ritual worship practices, the two madrasas also cresocially-orientednted programs. Practices of worship include donations, tau, shiah and slaughter of sacrificial animals. One of the goals is to instill students' social sensitivity towards others. The practice of worship is packaged in a program. MAN 2 Bandung, establishes spiritual development activities in the month of Ramadan and the slaughter of sacrificial animals in the month of Djulhijjah as madrasa programs. Meanwhile, MAN 2 Bandung Regency has set the Spiritual Friday activity and the slaughter of sacrificial animals in the month of Djulhijjah as a madrasa program. The two madrasas carry different concepts but have the same goals. The purpose of implementing this program is how students can have social sensitivity and be able to position themselves in society as humans who care and provide benefits to other humans. Meanwhile, the difference lies in the program itself and its technical implementation.

In its implementation, students as the target of fostering noble character formation in worship practices not only have a role as educational targets but also as worshipers. Meanwhile, the teaching staff has an important role to play in managing this program. Their job is not only to foster students,but also as 
facilitators for students. This habituation strategy is closely related to exemplary activities supported by training and assignments to students (Cinantya, 2019). The goal of making students have noble morals cannot be separated from the strategies that have been built.

Also, one of the methods used will depend on the figure of the educator. Because those who provide an example to students. This means that educators become a model for students. The strategy of forming noble morals by providing exemplary in current life conditions is very effective because students and even educators are role models or idols (Sutomo, 2014). The exemplary that he displays can be a powerful approach to shaping the noble morals of participants. students. Also, social relations that take place intensively between educators and students have accelerated the imitation process of students against the educators they imitate. This strategy has been implemented in the environment of MAN 2 Bandung City and MAN 2 Bandung Regency.

\section{2) Literacy Activities}

In general, the literacy program at MAN 2 Bandung City and MAN 2 Bandung Regency is divided into two categories of activities, namely general categories and special categories. The general category in question is literacy activities carried out by students while learning in class is in progress. Almost all subjects require students to have literacy skills. In this case, subject teachers usually provide time and space for students to first read the learning material that will be studied together. Meanwhile, a special category is literacy activities held outside of classroom learning hours. These literacy activities are usually more organized, organized, and sustainable. In it there are rules of the game that apply to all students.

The literacy program established by MAN 2 Bandung which is included in the general category is literacy activities that are integrated with subjects. Students get instructions from educators who teach certain subjects to read certain material. Meanwhile, the special category literacy program is that students are required to read the Koran before learning takes place. Besides, on Islamic holidays students make a manuscript of the Al-Quran. This activity applies to all students of MAN 2 Bandung City. Also, there is an activity called Intensive Islamic Studies (SSI) which is held every month of Ramadan for one week, and Language Month which is held once a year. One of the functions of this literacy program is the habituation of students to always carry and read the Al-Quran. This will have an impact on the internalization of the values contained in the Koran into the lives of students.

Meanwhile, the general category literacy program in MAN 2 Bandung Regency is not much different from MAN 2 Bandung City, namely literacy programs are integrated into every subject. Taking place in-class learning activities is an important part of the process of forming noble morals. Through the literacy process, students can increase their mastery of learning material which later the elements of good habituation will manifest into good action as well. Meanwhile, the literacy program in a special category, namely tadarus Al Qur'an, is carried out every day about 15 minutes before the learning process begins. Also, another program is the book reading activity which is held on the second Monday of every month. This activity applies to every grade level, from class X to XII. Implementation, activities guided by the chairman of the OSIS and Mojang Jajaka MAN 2 Bandung Regency. In this program, students are instructed to bring books. Students are allowed of about 10 to 15 minutes to read it. After that, representatives of classes $\mathrm{X}, \mathrm{XI}$ and XII were sent or voluntarily to deliver the results of their reading in front of other students.

\section{3) Extracurricular and Student Organization}

The noble moral formation program carried out by the two madrasas is through extracurricular programs and student organizations. The direct involvement of students in extracurricular activities and student 
organizations can be an effective medium in forming noble morals. The intense social process between students and coaches and with other students in activities will encourage the realization of the formation of noble morals. The presence of other students in extracurricular activities and other student activities has had a significant effect.

Extracurricular activities and student organizations are a place for students to actualize their potential based on their interests and talents. This can help to develop their potential in both academic and nonacademic fields, including the formation of noble morals. Psychologically and socio-culture, the process of moral formation in participants is a function of all individual potential, which involves cognitive, affective, and psychomotor aspects (Lestari \& Sukanti, 2016). Through extracurricular activities and student organizations, these three aspects can be developed and developed so that they can be manifested in moral behavior. This is influenced by the tendency of the students involved in it. These students are generally students with achievements in their fields so that a long social process will have an impact on the inculcation of good values in other students. This is an indicator of the process of internalizing the noble moral values of students. Therefore, this can help other students to improve their quality and have noble morals.

In the implementation of extracurricular activities in MAN 2 Bandung City and MAN 2 Bandung Regency emphasize the following principles: 1) individual, namely the principle of extracurricular activities according to the potential, talents, and interests of each student; 2) choice, namely the principle of extracurricular activities under the wishes and voluntary participation of students; 3) active involvement, namely the principle of extracurricular activities that require the full participation of students; and 4) fun, namely the principle of extracurricular activities in an atmosphere that is liked and makes the students happy.

The extracurricular activities at MAN 2 Bandung areas participants:

a) Scouts, Young Karana Praja Movement in MAN 2 Bandung City separated between sons and daughters. Ambalam Putera Salman Al-Farizi and Ambalan Princess Siti Jenab

b) Intra School Student Organization (OSIS) MAN 2 Bandung City

c) Youth Red Cross (PMR)

d) Olympiad / Subject Competition, specifically in MAN 2 Bandung, the Club is provided for the subjects of Physics, Chemistry, Economics, and Geography

e) Youth Scientific Group (KIR)

f) Art Activities, specifically for the environment of MAN 2 Bandung City has formed the Art Circle of MAN 2 Kota Bandung (LISMAN)

g) Sports activities, consisting of Volleyball Futsal, Basketball, Badminton, Taekwondo

h) Islamic Religious Activities, consisting of the Islamic Youth Forum (FORIS), Tahfidz and Tilawatil Quran and Keputrian

i) Flag Raising Troops (PASKIBRA)

j) Language field, which consists of English Club and Arabic Club

k) School Health Business (UKS) which includes Youth Health Cadres (KKR) and Youth Red Cross (PMR)

I) School Security Patrol (PKS)

While the extracurricular program at MAN 2 Bandung Regency includes the following fields and types of coaching activities:

a) Sports, which consists of Futsal, Volley Ball, Table Tennis, Badminton, Basketball, and Karate

b) Arts, which consists of Choir arts, Theater arts, Traditional / Degung arts, Marawis / Nasyid arts, and Calligraphy / Khot 
c) The National Insight Division, which consists of the Flag Raising Troops (PASKIBRA), Youth Red Cross (PMR), Scouts, Subject Lovers' Group, English Club, and Science Club

d) Fostering devotion to God Almighty, which consists of DKM, Student Da'wah Development,t and Tahfidz

e) Skills and Entrepreneurship Development, which consists of PIK-R and Student Cooperatives.

The student organizations that exist in the environment of MAN 2 Bandung City and MAN 2 Bandung Regency are the Intra School Organization (OSIS). This organization is the only organization in the madrasa that aims to provide coaching and student development. This organization becomes a forum for students, so that each student automatically becomes a member of the OSIS and that membership will automatically end with leaving the madrasa.

In addition to being a forum for students, this organization aims to prepare students as cadres to continue the ideals of the national struggle and human resources for national development, namely to: 1) develop the potential of students in an optimal and integrated manner which includes talents, interests, and creativity; 2) strengthen the personality of students to realize madrasah resilience as an educational environment to avoid efforts and negative influences and contradict the goals of education; 3 ) actualizing the potential of students in achieving superior achievements according to their talents and interests; and 4) preparing students to become citizens of society with noble character, democratic, respect for human rights in the context of realizing civil society. (Permendiknas No 39 of 2008, Chapter 1 article 1).

\section{4) Supporting Facilities and Infrastructure}

The implementation of the madrasah program will be maximally carried out, perhaps depending on the supporting facilities and infrastructure. This will be significant when there is a match between the means and the program being rolled out. The efficiency and effectiveness of program implementation are influenced by resources including facilities and infrastructure that can be maximized and implemented optimally.

According to Mulyasa in general, learning facilities and resources consist of two major groups, namely learning facilities and resources that are planned and utilized. Both types of facilities and learning resources can be utilized effectively in the successful implementation of noble character formation programs (Mulyasa, 2014. p.24).

MAN 2 Bandung City with existing facilities, such as a mosque, sports hall, and library building. Although the existence of these facilities and infrastructure is very vital and not yet representative, MAN 2 Bandung can maximize and optimize these facilities and infrastructure properly. Arrangements for the place, date, and ti, me of implementation are things that must be reviewed and considered before a decision is issued related to program implementation. That way, this becomes part of a strategy too to create moral students starting with a program that is facilitated with facilities and infrastructure that are not representative of the implementation of the program itself.

Likewise with MAN 2 Bandung Regency, supported by inadequate facilities and infrastructure, such as the unavailability of the Biology Laboratory, Physics Laboratory, Chemistry Laboratory, Hall, including places of worship can be circumvented and implemented with existing resources. MAN 2 Bandung Regency strives for the implementation of the noble character formation program carried out well, then MAN 2 Bandung Regency collaborates with other parties. MAN 2 Bandung Regency in collaboration with the management of the Great Mosque of Solokan Jeruk. Mosque as a means of worship as well as a means of worship practice for students of MAN 2 Bandung Regency. Apart from worship facilities, other 
facilities are also important, namely the hall and library. Improving the quality of students, especially aspects of cognitive or intellectual insight, is very much determined by adequate hall facilities and libraries.

\section{Supervision of Noble Moral Formation Program in MAN 2 Bandung City and MAN 2 Bandung Regency}

Supervision is an important part of the implementation of the noble character formation activity program. Each policymaker has a role and function in overseeing every programmed activity. Terry states that supervision is a follow-up activity related to efforts to identify program implementation that must be under the plan. There is a process of monitoring and correcting undesirable deviations so that the goal can be achieved properly. Improvements were made in various ways including changing plans, developing objectives, redistributing tasks, and adjusting policies and/or regulations (Terry, 2010).

Meanwhile, according to Sudjana the control measures can be formulated as follows.

1) Establish benchmarks regarding the results of achieving goals and activities to achieve these goals

2) Measuring the performance of the executor in carrying out activities

3) Comparing appearance with predetermined benchmarks

4) Improve the activities if deemed necessary so that the activities are following the plan (Sudjana, 2000).

The implementation of these steps in MAN 2 Bandung City and MAN 2 Bandung Regency is the first, the head of madrassas as the top leadership in educational institutions has the highest authority in the process of monitoring program implementation. He directly supervised various activities. He can also accept reports made by the party he leads. The leadership sets standards regarding the results to be achieved and the activities to be carried out. Second, the leadership measures the results that have been achieved and the activities that are being and have been carried out. Third, the leadership compares the actual results with the achievement of goals and factual activities with the goals that should be achieved and the activities that should be carried out. Fourth, the leadership together with the activity implementers improves the activities so that they are following the previous plan.

In addition to the principal of madrasah who has the function of supervising the entire program that has been planned, program officers or implementers also have the function of supervising the programs that have been and are being carried out. In this case, for example, both MAN 2 Bandung City and MAN 2 Bandung Regency held classroom coaching activities carried out by homeroom teachers. Here the homeroom teacher is responsible for supervising his class. However, the implementation of supervision between the two madrasas has differences. In MAN 2, Bandung Regency, the homeroom teacher controls every Monday the first hour of the 4th week of each month. Also, monitoring student discipline, is carried out by picket officers, picket officers, deputy head of student affairs, student staff, and the entire teacher council. This supervision is carried out every day.

Implementation of supervision in MAN 2 Bandung City and MAN 2 Bandung Regency carried out in a participatory manner under the control of the highest leadership. Each line in the organizational structure not only works and functions according to a predetermined line of duties which is in a different position from the other lines, but each line is connected. So that each line carries the same responsibility, namely realizing students who have a noble character based on the vision, mission, and objectives of the madrasa. Thus, the success of the formation of noble morals is not only the responsibility of the head of the madrasah, but also all madrasah members in the madrasa environment.. 
Evaluation of the Program for the Formation of Noble Morals in MAN 2 Bandung City and MAN 2 Bandung Regency

One of the educational management functions carried out while the program is being and has been implemented is evaluation. Evaluation is carried out on all or part of program components as well as on program implementation (Sudjana, 2000. p.263). Mulyasa said that the evaluation of the noble character formation program is related to decision making. In the process, assessment decisions are taken by students, educators, administrators, parents and community members who actively participate in determining which standards should be prioritized, other standards that are entered, and those involved in interpreting the data (Mulyasa, 2014).

Stufflebeam provides characteristics of the program implementation evaluation process which is divided into four activities or stages, namely describing, obtaining, reporting, and implementing. The four stages are carried out systematically and continuously. Through this stage, the evaluator can find out the success of a program (Stufflebeam \& Coryn, 2014).

First, describe. At this stage, the assessor is required to be able to interact with students and stakeholders who plan and determine the moral formation program. The judgment decision rests in the hands of the planning person. In this case, school members include educators, madrasah principals, madrasah supervisors, parents, and community members (Mulyasa, 2014). The purpose of this stage is to focus on evaluation related to questions, how to identify the community or madrasah members, clarify related values and criteria, determine information requirements, analyze required, develop evaluation ideas, and implement agreements to organize and facilitate evaluation activities.

Depiction activities include effective and interactive communication involving evaluators, students, and other interested parties which culminate in an agreement. The results of the illustrating actions form the basis for the next stage. In this case, both madrasas are fully aware that establishing relationships with madrasah citizens, madrasah supervisors, madrasah committees and parents of students is something that must be carried out properly. This is something that must be built to be able to plan, implement and assess the established programs. The participation of these parties has contributed to the assessment process.

The second earned. This stage includes all activities related to the process of gathering, correcting, organizing, analyzing, and synthesizing information. To obtain valid and reliable information, the assessors at MAN 2 Bandung City and MAN 2 Bandung Regency conducted data collection using observation, interview, test, and non-test techniques.

Furthermore, Mulyasa emphasizes the efforts to develop noble character formation programs that are considered, among others, related to the quality of the program and implementation of the formation of noble morals, the quality of the learning environment of students as well as activities, processes, and learning outcomes. The data were collected and analyzed by the evaluators using qualitative and quantitative approaches. The criteria used to process and interpret the data include technical indicators, pedagogical criteria, and critical indicators (Mulyasa, 2014).

Third reporting. This stage is an activity carried out by the evaluator who provides feedback to students and other parties. The form of evaluation can be in the form of an analysis result which is converted into a report form. This process includes the preparation and submission of reports either orally or in writing, which are packaged through program evaluation forums or work meeting forums. In it, the parties involved in designing and administering the program exchange information, including with students. 
Problems and constraints found by the authorities in supervising the activities carried out by students are used as material for evaluating the implementation of the program. Subject teaching educators, for example, who deal directly with students, report problems they encounter related to the actions of students and then report them to the counseling guidance teacher. The counseling guidance teacher who follows up on the problem also conducts evaluations and makes reports which are then submitted to the madrasah leadership. This process is then followed up and discussed in leadership meetings which are held regularly in leadership meetings.

The essence of the reporting activity is to communicate the assessment findings in an effective, accurate, and timely manner to interested parties and those who have the right to know them to encourage the use of the evaluation findings. This party is the program implementer who is obliged to monitor and review the development of the noble character formation program as well as the stakeholders. Educators report from the activity plan. In MAN 2 Bandung City and MAN 2 Bandung Regency, educators who teach the subjects make reports on the development of noble morals based on the instruments contained in the RPP. The lesson plans that are made contain elements of moral learning that are designed following the design of classroom management. In the learning process, educators are directly involved and have a dialogue with students.

Fourth, applying, namely the stages in which students and other parties have a share in applying the results of the evaluation. Besides, their participation can be in the form of criticism and input, coordination and deliberation, workshops, and so on. Involving students in implementing evaluation results is very influential on the success of the formation of noble morals. To be effective in supporting the application of evaluation results, evaluators know the principles and changes in procedures and research on the use of evaluations

To develop a noble character formation program, attention is paid to, among other things, the quality of the program and the implementation of the formation of noble morals, the quality of the learning environment of students as well as the activities, processes, and learning outcomes. The data were collected and analyzed by the evaluators using qualitative and quantitative approaches. The criteria used to process and interpret the data include technical indicators, pedagogical criteria, and critical indicators. Data processors, decision-makers, and users are those who are involved in the moral formation program.

\section{The Influence of the Environment on the Implementation of the Moral Formation Program in MAN 2 Bandung City and MAN 2 Bandung Regency}

The influence of the environment on the implementation of the formation of noble morals is influenced by two factors, the first is internal factors. This factor comes from within the institution, the availability of resources, both human resources and facilitie,s and infrastructure to support the implementation of the formation of noble morals. Meanwhile, external factors are factors that come from outside. Thus, the success of forming the noble character of students is also influenced by environmental aspects that come from outside.

For MAN 2 Bandungtwo sources of influence comeme from outside, namely academic and non-academic factors. Akadamis factor is a factor that manifests itself in academic cultures. This is driven by the existence of universities around the madrasah, both private and state universities. So that the academic cultures in the university environment influence the academic culture at the Madrasah Aliyah (MA) level. Meanwhile, non-academic factors such as socio-economic conditions and communication technology also influence the process of forming the noble character of students. The socio-economic conditions of students can encourage students to have noble morals, but can also push in the opposite direction, to become learners who have disgraceful morals. Communication technology has influenced students about 
how they behave and play a role in society. The use of communication technology is packed with various complete features, such as social media applications, games and others. ,The morals that appear in students are greatly influenced by how they use this technology.

Similar conditions are also faced by MAN 2 Bandung Regency. There are twTwo factors influencentation of the formation of noble morals. First, internal factors related to conditions in madrasah, both related to ta he availability of human resources and resources to support activities. The influence that comes from within the institution comes from what is available and how to make the best use of these resources. The availability of competent teaching staff, supported by infrastructure, can facilitate the implementation of the formation of noble morals.

Second, external factors related to socio-economicare and geographic conditions. MAN 2 Bandung Regency is influenced by the existence of Industry. Located in the vicinity of an industrial area is a challenge for MAN 2 Bandung Regency to be able to develop the noble character formation of students. This makes it difficult for the madrasah to build communication with the parents of students. This limitation actually affects the cnd monitoring process carried out by educators in the madrasa environment and parents in their family environment. So that the process of coaching students is only centered and takes place in the madrasah environment.

\section{Problems and Solutions of Problems that occur in MAN 2 Bandung City and MAN 2 Bandung Regency}

The problems faced by MAN 2 Bandung City and MAN 2 Bandung Regency related to the formation of morals are divided into two problems. First, problems that come from within. This condition stems from within the institution where problems related to resources arise. Resources in question are resources that include human and non-human resources. Human resources relate to the parties involved in the formation of noble morals, including educators, education personnel, madrasah heads, administrative staff, madrasah supervisors, madrasah committees, parents of students. Meanwhile, non-human resources are related to learning facilities and resources.

Some of the problems experienced by the two madrasas are the availability of educators who do not have sufficient competence. The skills of educators in educating and providing guidance to students have not been fully implemented optimally. Madrasahs are faced with a lack of applicative ability of educators in providing education to students. In addition, the theAlsoty of support for the implementation of moral formation is a serious problem for madrasas. This is one of the obstacles to the formation of noble morals.

Second, problems that come from outside MAN 2 Bandung City and MAN 2 Bandung Regency are faced with the same problem, namely the implementation of a noble character formation program in the midst of globalizainsingly rapid technological advances. So that this condition gives birth to social change which is also a problem that is difficult to contain. The flow of globalization and modernization has influenced the style and character of society, including students. This is a challenge that cannot be avoided and the best solution must be formulated to handle it.

Globalization has given birth to a new social order in which members of society are interconnected and there are no boundaries between community members. This condition has entered the lives of students, where they find it easy to access and receive information that comes from outside. This can have the potential for behavior change in them due to the mixing and acceptance of new elements or cultures that are not in accordance with the values and nofollowingty. 
The solution to the first problem related to the competence of educators is how educators are able to provide the best sercandents. Educators are the executors of the noble character formation program which has a very big influence. He can determine the success of the formation of noble morals in students. In implementing the noble character formation program, MAN 2 Bandung City and MAN 2 Bandung Regency motivate educators to become a figure or idol for students so that they can provide good role models for them.

For this reason, in the process of cultivating noble moral values, educators in the MAN 2 Bandung City and MAN 2 Bandung Regency environments, always establish a harmonious relationship and involve themselves in the activities of students. This is an effort to reduce the unsuccessful formation of noble morals in students. Its function is that educators can directly monitor and foster the activities carried out by students. For example, one of the noble morals formation programs in the two madarah is the congregational prayer dzuhuMandurahators are not only sufficient to lead students to perform ablution immediately and follow congregational prayers, but educators also do the same with students. Thus, in these conditions the educator does not only play a role in providing an example, but becomes an example for students. Therefore, the two madrasas prepare and plan various training to increase the competence of teaching staff.

In addition to educators who deal directly with students, other components that must also participate in the successful implementation of the noble character formation program are the community environment, leaders, policy makers, community authorities and parents. These parties must be good role models in instilling noble moral values in students. This is because various bad and inconsistent behaviors shown by the community, both directly and indirectly, will also contribute badly. This will have an impact on the moral shift of students towards a worse direction.

The next solution is to create a conducive environment. This environment has fun learning facilities for students. Harmonious social relationships between educators and students, parents of students and educators and with other students will create order in the madrasah environment. So that it can give birth to a learning climate that is fun and not boring. That way, when students learn with a happy feeling, it will have the potential to give birth to student activity, creativity and productivity.

\section{CONCLUSION}

Education is a conscious and planned effort in order to instill values in students in order to create competitive and noble human beings. Meanwhile, madrasas as educational institutions are at the forefront of responding to the challenges of globalization and advances in science and technology which not only have positive but negative impacts on people's lives. Decadence of morals among adolescents is one of the negative impacts it causes. Of course, through education, efforts to overcome these problems can be overcome with various breakthroughs and innovations in moral formation programs so as to reduce the high level of moral decadence. Through a system of chanting the formation of proper morals along with the right programs, education can contribute greatly to society in realizing the birth of a generation with noble character. Therefore, the principle of management in the formation of noble morals is very important in order to achieve students who not only have intellectual intelligence obtained through the cognitive learning process, but also have social and spiritual intelligence.

MAN 2 Bandung City and MAN 2 Bandung Regency implement the principles of educational management in the framework of forming the noble morals of students by carrying out the planning, implementation, monitoring, monitoring and evaluation processes. In addition, there is an effort to identify problems that arise, whether they come from within or from outside to find solutions to problems and find solutions with 
the aim of improving the noble moral quality of students in accordance with the vision, mission and goals of the madrasa.

\section{REFERENCE}

Arikunto, S. (2005). Prosedur Penelitian Suatu Pendekatan Praktek. PT Rineka Cipta.

Berkowitz, M. W., \& Bier, M. C. (2005). What Works In Character Education: A Research-Driven Guide for Educators. Univesity of Missouri St Louis.

BKKBN. (2016). Kalangan Remaja Kurang Peroleh Informasi Seks Tuntas. http://www.bkkbn.go.id

Cinantya, C. (2019). The Strategy of Religious-Based Character Education in Early Childhood Education. International Journal of Innovation, Creativity and Change, 5((5)).

Depdiknas. (2003). Undang-Undang Nomor 20 Tahun 2003 Tentang Sistem Pendidikan Nasional. Depdiknas RI.

Djailani, A. R. (2013). Teknik Pengumpulan Data dalam Penelitian Kualitatif. Majalah IImiah Pawiyatan, $\mathrm{XX}((1))$.

Fitri, L. (2017). Faktor-Faktor yang Berhubungan dengan Tindakan Seksual Siswa. Jurnal Penelitian Kesehatan Suara Forikes, VIII((2)).

Kementerian Kesehatan RI. (2017). Infodatin Anti Narkoba Sedunia 27 Juni 2017. Pusat Data dan Informasi Kementerian Kesehatan RI.

Koesoema, A. D. (2010). Pendidikan Karakter Strategi Mendidik Anak di Zaman Global. PT. Grasindo.

Lestari, P., \& Sukanti. (2016). Membangun Karakter Siswa Melalui Kegiatan Intrakurikuler Ekstrakurikuler, dan Hidden curriculum (di SD Budi Mulia Dua Pandeansari Yogyakarta). Jurnal Penelitian, 10((1)).

Lickona, T. (2013). Pendidikan Karakter: Panduan Lengkap Mendidik Siswa Menjadi Pintar dan Baik. Nusa Media.

Mujieb, M. A. (2009). Ensiklopedi Tasawuf Imam Al-Ghazali Mudah Memahami dan Menjalankan Kehidupan Spiritual. Hikmah Mizan Publika.

Mulyasa, E. (2014). Manajemen Pendidikan Karakter. Bumi Aksara.

Mulyasana, D. (2011). Pendidikan Bermutu dan Berdaya Saing. PT Remaja Rosda Karya.

Nata, A. (2009). Akhlak Tasawuf. Rajawali Press.

Njoku, N. C. (2016). Teachers' Perception on the Dimensions of Moral Decadence among Secondary School Students in Ebonyi State, Nigeria. Journal of Education and Practice, 7((26)), 187-191.

Nursanti. (2014). Manajemen Peningkatan Akhlak Mulia di Sekolah Berbasis Islam. Jurnal Kependidikan, II((2)), 47-65.

Rahardjo. (1999). Pemikiran Pendidikan Islam, Kajian Tokoh Klasik dan Kontemporer. Pustaka Pelajar.

Raharjo, S. B. (2010). Pendidikan Karakter sebagai Upaya untuk Menciptakan Akhlak Mulia. Jurnal Pendidikan Dan Kebudayaan, 16((3)), 229-238.

Samanai, Muchlas, \& Hariyanto. (2017). Konsep dan Model Pendidikan Karakter. PT Remaja Rosda Karya.

Sanusi, A. (2015). Sistem Nilai. Nuansa Cendikia.

Sauri, S., \& Firmansyah, H. (2010). Meretas Pendidikan Nilai. Arfino Raya. 
Sholihin, M., \& Anwar, M. R. (2005). Akhlak Tasawuf, Manusia, Etika, dan Makna Hidup. Nuansa.

Stufflebeam, D. L., \& Coryn, C. L. S. (2014). Evaluation Theory, Models, and Applications. Jossey-Bass.

Sudjana, D. (2000). Manajemen Program Pendidikan untuk Pendidikan Luar Sekolah dan Pembangunan Sumber Daya Manusia. Falah Production.

Sutomo, I. (2014). Modification of character education into akhlaq education for the global community life. IJIMS, Indonesian Journal of Islam and Muslim Societies, 4, 291-316.

Tafsir, A. (2005). Ilmu Pendidikan dalam Perspektif Islam. PT. Remaja Rosdakarya.

Tantowi, A. (2008). Pendidikan Islam di Era Transformasi Global. PT Pustaka Rizki Putra.

Terry, G. R. (2010). Prinsip-Prinsip Manajemen. PT. Bumi Aksara.

Ya'cob, H. (1978). Etika islam. CV. Publicita. 